\title{
Scaffold Flatness: Reversing the Trend
}

\author{
Fatemeh Mazraati Tajabadi • Marc R. Campitelli • \\ Ronald J. Quinn
}

Received: 29 March 2013/Revised: 3 October 2013/Accepted: 7 October 2013/Published online: 23 October 2013

(C) The Author(s) 2013. This article is published with open access at Springerlink.com

\begin{abstract}
Fraction $s p^{3}\left(\mathrm{~F}_{s} p^{3}\right)$ values were used to compare the flatness of known scaffolds (used as privileged structures, drug scaffolds, and in scaffold-hopping approaches) and natural product (NP) scaffolds. The vast majority of the known synthetic scaffolds are planar with F $s p^{3}$ values $<0.45$ while the NP scaffold set is composed of mainly non-flat scaffolds. The identification of new or novel scaffolds to provide libraries of small diverse bioactive compounds is of the utmost importance to chemical biology and medicinal chemistry research. Non-flat scaffolds embedded in NPs may explore neglected areas of chemical space. We performed a scaffold abstraction from the dictionary of natural products (DNP), which resulted in 15,822 scaffolds. From this scaffold set, the vast majority (70\%), are non-flat scaffolds with $\mathrm{Fsp}^{3}$ value $>0.45$. These non-flat scaffolds may cover $83 \%$ of ring systems that are absent from screening set.
\end{abstract}

Keywords Scaffold · Scaffold flatness · Fraction $s p^{3}$. Natural product scaffolds

\section{Introduction}

"Chemical space" is vast, even the subset of the chemical universe that is of interest to drug development of molecular weight (MW) $<500 \mathrm{Da}$ is estimated to number $\sim 10^{60}$

F. M. Tajabadi · M. R. Campitelli · R. J. Quinn ( $ه)$ Eskitis Institute for Drug Discovery, Griffith University, Brisbane, QLD 4111, Australia e-mail: r.quinn@griffith.edu.au

F. M. Tajabadi

e-mail: fatemeh.mazraatitajabadi@griffithuni.edu.au;

fatemehmazraati@yahoo.com
[17]. This number is out of the practical range for synthetic accessibility and not surprisingly, chemists have covered only a tiny portion of this space. According to SciFinder $\sim 10^{7}$ chemical structures have been reported, to date. Bioactive molecules generally exert their effect through interaction with proteins so that biological space is significantly more limited. Proteins are limited in their combinations of 20 different of amino acids, and the human genome for instance, encodes only 20,000-25,000 proteincoding genes (Consortium IHGS [11]). Binding molecules are recognized by the protein in specific binding pockets, complementary in shape and physicochemical properties to the accommodated small molecule [57]. Biologically relevant chemical space (BRCS) is just a tiny fraction of the complete chemical space [13]. It is worthwhile mentioning that "drug space" is even smaller than BRCS, such that not every bioactive molecule presented in BRCS can be considered as a drug molecule. Drug space contains those bioactive molecules that have favorable potency, selectivity, and pharmacokinetic properties (absorption, distribution, metabolism, and excretion) for use as a drug [32].

To cover the expanse of BRCS, it is necessary to avoid strategies that generate structurally similar compounds with similar biological profiles. However, current approaches suffer from insufficient overlap of compounds (usually from synthetic libraries) and biological structure space [58]. Optimization of the processes of producing new chemical entities to help match chemical and biological space is of great significance to modern drug discovery. Several approaches, such as libraries of privileged scaffolds, scaffold-hopping, diversity-oriented synthesis (DOS), and biology-oriented synthesis (BIOS) have been introduced to address the issue.

Molecular scaffolds (core structures) play a fundamental role in the navigation of "biologically relevant chemical 
space" and drug development. Identification of new scaffolds that have potential to provide libraries of small diverse bioactive compounds is of utmost interest to chemical biology and medicinal chemistry research. Several studies have been directed toward the assessment of scaffold diversity of drug data sets [4, 20, 55], screening libraries $[24,29,50]$, organic compounds databases [34, 59], and natural product (NP) databases [20, 24, 27]. These studies show that scaffold space is vast and diverse while bioactive and drug-like compounds only represent a small fraction of principally available scaffold space [30], suggesting that scaffold selection is important.

Natural products and their analogs have had high impact as drugs because of the embedded biosynthetic molecular recognition that transfers to therapeutic targets as described by protein fold topology (PFT) [26, 38]. Computational analysis revealed that NPs exhibit a remarkable structural diversity of molecular frameworks and scaffolds. They possess desirable drug-like properties rendering them ideal starting points for the design of focused libraries [20]. Approximately $40 \%$ of the chemical scaffolds displayed in NPs are absent from synthetic compounds [31]. Furthermore, according to Hert et al. [24] $83 \%$ of the ring scaffolds among the NPs are unrepresented among commercial molecules. More complex molecules have the capacity to access greater chemical space and results in greater potential for compounds to complement the spatial subtleties of target proteins [36].

We performed a statistical analysis on the known scaffolds presented in three different reviews, i.e., scaffoldhopping, privileged scaffolds, and drug-building blocks [54-56] to determine the proportion of the scaffolds that were planar. The "Carbon bond saturation" defined by fraction $s p^{3}$ value $\left(\mathrm{F}_{s} p^{3}\right)$ was used to classify flat and nonflat scaffolds [36]. We undertook a scaffold abstraction from the dictionary of natural products (DNP) to determine the proportion of flat scaffolds $\left(\mathrm{F} s p^{3} \leq 0.45\right)$ versus non-flat scaffolds $\left(\mathrm{F} s p^{3}>0.45\right)$. Non-flat scaffolds have a potential to introduce new anchor points to explore additional areas of "biologically relevant chemical space". Increased outof-plane substituents may translate to increased selectivity in interactions with proteins. The analysis shows that NP scaffolds have a higher proportion of non-flat members compared to set composed of scaffold-hopping, privileged scaffolds, and drug-building blocks.

\section{Two Sources of Chemical Space}

Current chemical space includes compounds isolated from nature, and those synthesized by different strategies. Although NPs interrogate a different and larger area of chemical space than synthetic compounds [18, 48], drugs derived from both spaces show similar values for Lipinski parameters. Lipinski's "rule of five" (Ro5) has been proposed to evaluate the drug-likeness of a chemical compound, based on the physico-chemical properties [33]. About $80 \%$ of NPs have less than two violations of the Ro5 [45]. Overall, NPs are more similar to drugs than compounds obtained from combinatorial synthesis [16]. Drug molecules are generally developed from less complex lead compounds, so that lead compounds usually have a smaller number of rings, fewer rotatable bonds, and smaller MW and are more hydrophilic than the final drug molecule [21].

\section{NPs as a Source of Drug Leads}

Historically, NPs have proven to be one of the richest sources of active ingredients of medicines. They are biosynthesized by enzymes within organism as primary or secondary metabolites. Unlike primary metabolites, the absence of secondary metabolites does not result in immediate death, but the molecules may play an important role in organism survival. Some NPs have been evolutionary preselected to modulate biochemical pathways as toxins, pheromones, attractants, and repellents. The medical outcomes far exceed the conversion of these natural systems into drugs and, for example, in the area of cancer, of the 175 small molecules therapeutics developed between 1940s and 2010, 48.6\% are NPs or directly derived thereof (Newman and Cragg [41]).

High-quality libraries for high throughput screening (HTS) are of the utmost importance to modern drug discovery. Some technical drawbacks associated with NPs render these molecules unfavorable for HTS [28]. The major problems include the problem of the inherent slowness of working with NP extracts using bioassay-guided isolation [23]. Therefore, traditional iterative NP extraction and isolation methodology cannot be easily integrated into modern drug development programs. Several methods and strategies have been developed to promote the speed and efficiency of the NP discovery process. The introduction of fractionation and advances in structure elucidation has been a great step forward in fulfilling this goal [7-9, 22, 51, 62].

\section{Combinatorial Chemistry as a Solution}

For more than a decade, a super rapid method of synthesis, combinatorial chemistry, promised to help solve the productivity issue for HTS that would lead to a wealth of new drugs. As a result, pharmaceutical companies started to invest in making large libraries based on this strategy, which resulted in a significant decline in attention toward NPs. The focus of combinatorial chemistry was on quantity, with insufficient attention given to quality. Although combinatorial chemistry techniques proved to be successful in the optimization of structures of many recently 
Fig. 1 Benzodiazepines and some of their numerous biological properties

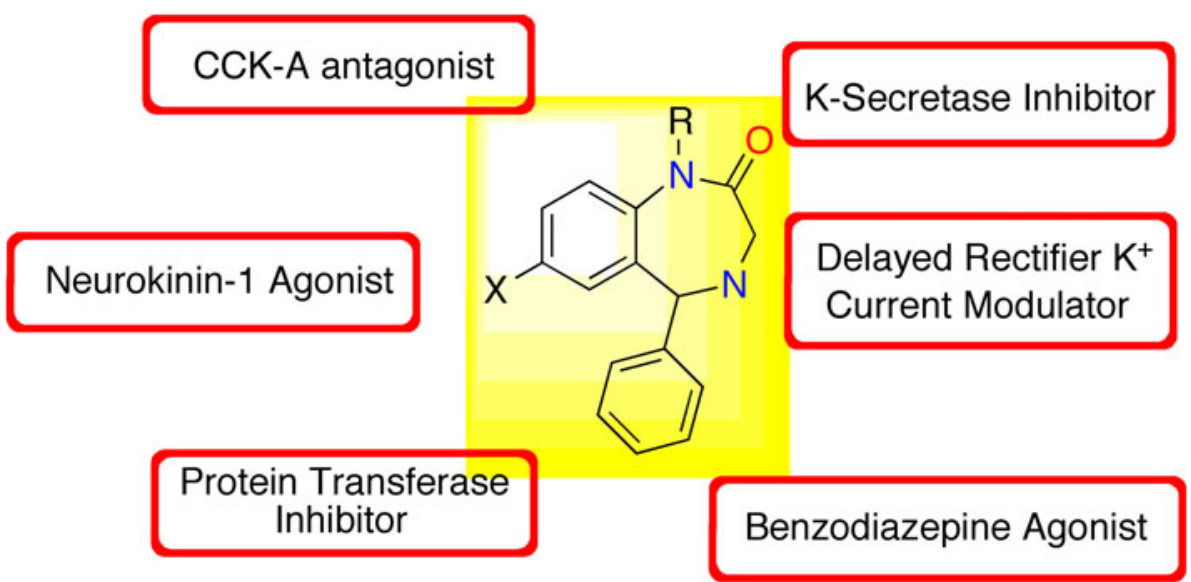

approved drugs, the number of new drugs has not increased significantly $[12,14,52]$.

\section{Two Alternative Approaches}

Two main approaches, diversity-oriented synthesis (DOS) and libraries of "privileged structures" have emerged to address the inherent combinatorial chemistry's shortfalls [40]. Lessons learned from NPs are beginning to impact on synthetic strategies.

\section{Diversity-Oriented Synthesis}

DOS aims to maximize the number of structures and scaffolds produced from a given synthetic scheme to find the most efficient ways to populate the largest amount of chemical space. In order to achieve the highest levels of structural diversity: (i) the building blocks, (ii) the stereochemistry, (iii) the functional groups and, most importantly, and (iv) the molecular framework must be varied [5]. A wide variety of libraries has been made based on this approach $[39,44,53]$. Recently, a new concept of DOS, so-called biology-oriented synthesis (BIOS) has developed [27]. In BIOS, NP scaffolds are employed as a core and diversity is created around it. Several libraries have been generated using this strategy resulting in discovery of protein phosphatase inhibitor [42], protein tyrosine phosphatase inhibitor [43], estrogen receptor $\alpha / \beta(E R \alpha / \beta)$ inhibitor, and 5-LOX inhibitors [60]. A "parent-child scaffolds" concept was derived from a "structural classification of natural products (SCONP)" tree [6]. In fact, combining the results of SCONP with the structural classification of proteins "PSSC" was a great step toward the developing concept of BIOS.

\section{Libraries of Privileged Scaffolds}

Another important strategy to guide synthetic design and to help enrich compound collections in biological activities is that of privileged structures. The concept of privileged structures was first proposed in relation to benzodiazepines that bind to multiple, unrelated classes of proteins as high affinity ligands (Fig. 1) [15].

Research over the next three decades has revealed more privileged structures [46]. Recently, a comprehensive list of privileged structures has been assembled [56]. According to the IUPAC definition, a privileged structure is a substructure "that often consists of a semi-rigid scaffold, which is able to present multiple, hydrophobic residues without undergoing hydrophobic collapse." In this way, the core preserves most of the binding potential when the compound is exposed to an aqueous medium [3]. The evolving role of NPs in drug discovery to provide effective drugs supports the idea that NPs can be viewed as a population of privileged structures selected by evolutionary pressures to interact with a wide variety of proteins [26, 28]. NP-like libraries based on privileged scaffolds attempt to rapidly generate large collections of compounds that possess greater diversity and incorporate optimized physical and pharmacological properties into their structures. Interestingly, these libraries also provide a useful tool in the identification of new targets [1,49].

\section{How Diverse are the Known Scaffolds?}

Molecular scaffolds play an important role in providing the tools to interrogate BRCS and in drug development. The identification of new scaffolds is of utmost importance to chemical biology and medicinal chemistry research.

The term scaffold is context- and chemist-dependant. In chemoinformatics, "the term scaffold is mostly applied in a rather subjective manner without adhering to clear, formal and consistent definition" [25]. In most cases, the term scaffold has been used interchangeably either as core structure, building block, substructure, template, ring system (RS), and/or framework. One of the most interesting types of study of scaffolds is in the assessment of scaffold diversity. Diversity analysis of scaffolds has been done on 
various databases including drug data sets [4, 20, 55], screening libraries [24, 29, 50], organic compounds databases [34, 59], and NP databases [20, 24, 27]. These studies show that scaffold space is vast and diverse while bioactive and drug-like compounds represent a small fraction of principally available scaffold space [30], suggesting that there are many scaffolds that can be systematically exploited. NPs, as a source of therapeutically useful compounds, are biosynthesized through interaction with proteins, and carry-forward the "embedded" molecular recognition through interactions with drug targets [26, 38].

The majority $(80 \%)$ of NPs possess desirable drug-like properties [45]. In a similar fashion, computer-based analysis revealed that NPs exhibit a remarkable structural diversity of molecular frameworks and scaffolds with desirable drug-like properties rendering them ideal starting points for the design of focused libraries [20]. Approximately $40 \%$ of the chemical scaffolds displayed in NPs are absent from synthetic compound [31]. Making NP-like libraries to create more complex, drug-like compounds has the capacity to access greater chemical space [36].

\section{Escape from Flat Scaffolds}

Aromatic and heteroaromatic rings comprise a significant proportion of compounds in "drug space," however, the developability of compounds (efficacy, pharmacokinetics, pharmacodynamics, toxicology, and drug-drug interactions) decreases with increasing number of aromatic rings [47]. Insertion of aromatic rings into drug-like compounds is used to increase the potency of compounds because an aromatic ring possesses fewer degrees of freedom than acyclic chains, and this favorable entropy generally increases the ligandreceptor-binding energy leading to improved potency [47]. The prevalence of aromatic and heteroaromatic rings in drug molecules has been attributed to the synthetic ease [47]. Making compounds with aryl-aryl systems are more time and cost effective. This is due to the fact that most of the available synthetic methodologies and chemical substances (both substrate and building blocks) are based on flat aromatic systems. Limiting the number of aromatic rings in a drug candidate will make it more "drug-like" [47].

Compounds with a greater fraction of saturated carbons (defined by $\mathrm{Fsp}^{3}$ ), which is an intuitive measure of complexity, have a higher access rate in the drug discovery process [36]. The Fsp ${ }^{3}$ as a simple and interpretable measure of complexity of molecules is defined as:

$F s p^{3}=\left(\right.$ Number of $s p^{3}$ hybridized carbons/Total carbon count $)$.

More highly complex molecules, as measured by saturation and number of chiral centers, have the capacity to access greater chemical space [36].
Flatness Investigation of the Known Scaffolds

A flatness investigation has performed in order to classify scaffolds that have been used in approaches involving scaffold-hopping, privileged sub-structures, and drug RSs. Based on some calculated mean $\mathrm{F}_{s}{ }^{3}$ value reported for drug data sets $[10,35,36]$, we defined flat and non-flat scaffold as follows:

Flat scaffold: scaffolds with $\mathrm{F} s p^{3} \leq 0.45$.

Non-flat scaffold: scaffolds with $\mathrm{Fsp}^{3}>0.45$.

\section{Classification of Scaffold-Hopping Approaches}

Sun et al. [54] recently reviewed approaches to scaffoldhopping. By making certain changes to the original scaffolds such as heterocyclic replacements, ring opening or closure, pseudopeptides, and topology-base hopping [54], there is possibility to produce novel scaffolds. In practice, since many of the original scaffolds came from flat molecules, the final scaffolds rarely have novel 3-D orientation of substitutions. The review classified the number of structurally diverse scaffolds into four categories based on the degree of novelty compared to the starting scaffold. For example, rimonabant, a failed antiobesity drug, was transformed by scaffold-hopping approaches to a novel CB1 antagonist with improved pharmacological properties. The change in the original scaffold to create the new scaffold is classified as first degree of novelty, with a small change of heteroatom or ring size. In this case, the methylpyrazole core in rimonabant was replaced with a range of five- and six-member heteroatom rings to overcome undesirable physicochemical properties [54]. Furthermore, the scaffolds that have been used more recently (March-October 2012) in a scaffold-hopping approach have also been examined based on their flatness feature [2, 19, 37, 61, 63-65].

Based on our defined criteria, we sorted the scaffolds as flat and non-flat scaffolds (Fig. 2). The vast majority of scaffolds $(89 \%)$ utilized in scaffold-hopping have incorporated planar frameworks (Fig. 3).

\section{Privileged Scaffolds for Library Design and Drug Discovery}

One of the most comprehensive listings of privileged scaffolds (PS) has published by Welsch et al. [56]. The authors provided a list of privileged scaffolds in drug and NPs, those found primarily in drugs, and other examples of privileged scaffolds. The authors stated that "there is a remarkable overlap between structures of drugs and NPs classes as the greater number of scaffolds have members from both groups". We have classified the privileged scaffolds in the review by Stockwell et al. as flat and 
Fig. 2 Flatness classification of the scaffolds that have been used in scaffold-hopping approach

Flat scaffolds
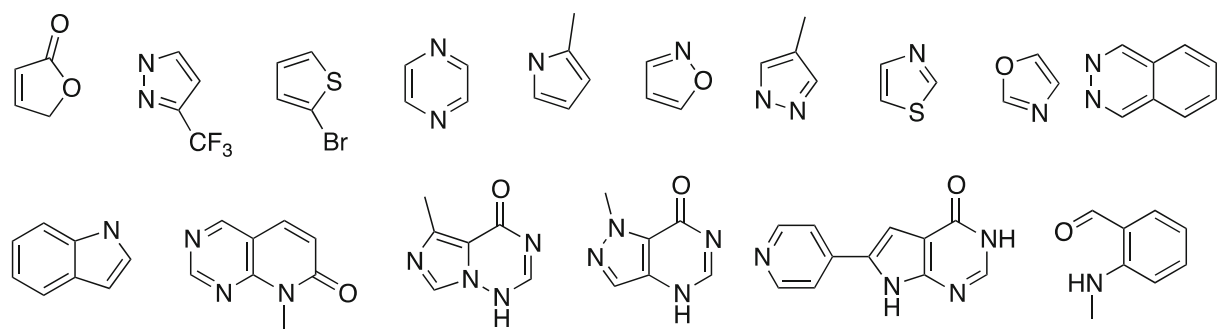<smiles>O=c1[nH]cnc2[nH]c(-c3ccncc3)cc12</smiles><smiles>CNc1ccccc1C=O</smiles><smiles>CNc1ccccc1C</smiles><smiles>CNC(=O)Nc1ccncn1</smiles><smiles>CN1CCC(=C2c3ccccc3C=Cc3ccccc32)CC1</smiles><smiles>CN1CCC(=C2c3ccccc3CCc3cccnc32)CC1</smiles><smiles>CN1CCC(=C2c3ccccc3CCc3sccc32)CC1</smiles><smiles>CN(C)CCC(c1ccccc1)c1ccccc1</smiles><smiles>NC(=O)c1ccc(-c2c[nH]nc2N)cc1</smiles><smiles></smiles><smiles>Clc1ccc(OC2CCNCC2)cc1Cl</smiles><smiles>CC(=O)[C@H]1CNC[C@H]1c1ccc(/C=C/C(=O)Nc2ccccc2N)cc1</smiles><smiles>CS(=O)(=O)c1ccc(C2Nc3ccccc3C(=O)N2c2ccccc2)cc1</smiles><smiles>CC1(C(N)=O)CCCN1S(=O)(=O)c1ccccc1</smiles><smiles></smiles><smiles>O=C1NC(=O)C(=Cc2ccccc2)C(=O)N1</smiles><smiles>Cc1ccc(C=C2C(=O)NC(=S)N(C)C2=O)o1</smiles><smiles>Cc1cc(C)c(N2c3ncccc3NC2SCC(N)=O)c(C)c1</smiles><smiles>O=CN1CCC(c2ccccc2)=N1</smiles>

Non-flat scaffolds

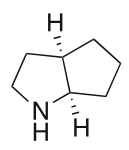<smiles>C1CC2(CCN1)CC2</smiles><smiles>O=CC1CCCN1</smiles><smiles>CC(O)[C@H](O)[C@@H](O)C1OC(C(=O)O)=CC[C@H]1CO</smiles>

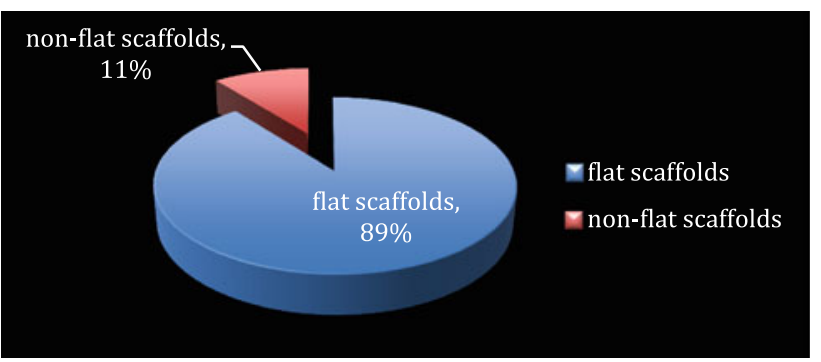

Fig. 3 The distribution of flat and non-flat scaffolds in scaffoldhopping approach

non-flat according to our previously defined $\mathrm{Fsp}^{3}$ definition of flatness (Fig. 4). The privileged scaffolds in drug and NPs are colored red, the PS found primarily in drugs colored in violet and other examples of privileged scaffolds colored in black. As demonstrated in Fig. 5, only a small fraction $(23 \%)$ of the privileged substructures are saturated non-flat scaffolds with at least one chiral centre. This observation again implies that there has been a significant bias toward using flat aromatic or heteroaromatic rings by chemists according to earlier discussed reasons (ease of synthesis and conformational restriction to increase the potency of compounds).

\section{Drug and Drug Candidate-Building Block Analysis}

Wang and Hou [55] undertook a drug-likeness analysis in 2010. In this work, two drug data sets and one screening data set were subjected to building block analysis. The data 
Fig. 4 Flatness classification of the scaffolds that have been used in a library of privileged structures. (The privileged scaffolds in drug and NPs colored red; the PS found primarily in drugs colored violet and other examples of privileged scaffolds colored black)
Flat privileged scaffolds<smiles>c1ccc2ncccc2c1</smiles><smiles>c1nc2[nH]c3cncc2c3n1</smiles><smiles>c1ccc2nccnc2c1</smiles><smiles>O=c1[nH]cnc2ccccc12</smiles><smiles>c1ccc2c(c1)NCCO2</smiles><smiles>c1ccc2occc2c1</smiles><smiles>CC1(C)C=Cc2ccccc2O1</smiles><smiles></smiles><smiles>O=C1Nc2ccccc2C1(O)O</smiles><smiles>c1ccc2c(c1)CCNC2</smiles><smiles>NCCN(Cc1ccccc1)c1ccccc1</smiles><smiles>O=C1CN=C(c2ccccc2)c2ccccc2N1</smiles><smiles>c1ccc(-c2ccccc2-c2nnn[nH]2)cc1</smiles><smiles>C1=CCNC=C1</smiles><smiles></smiles><smiles>c1ccc2sccc2c1</smiles><smiles>c1ccc(-c2nc3ccccc3s2)cc1</smiles><smiles>c1ccc2c(c1)NCc1cncn1-2</smiles><smiles>Nc1cccnn1</smiles><smiles>O=C1CSC(=O)N1</smiles><smiles>O=c1ccc2ccccc2[nH]1</smiles><smiles>c1ccn2cccc2c1</smiles><smiles>c1ccc2c(c1)CCN2</smiles><smiles>[X]C1=NC(Br)C([R])=C([R])N1</smiles><smiles>[R5]C1CN([R])c2cn([R5])nc2C(=O)N1</smiles><smiles>[R7]CC1C=CCOC2C=CNC(=O)C12</smiles><smiles>[R5]C1=CN[C@H](C2=CNC([R5])(C3=CNC([R7])([R7])C3=O)C2=O)C1=O</smiles>

Non-flat privileged scaffolds<smiles>C1CCC2C(C1)CCC1C3CCCC3CCC21</smiles><smiles>OCC1OC(O)C(O)C(O)C1O</smiles><smiles>C=C1C(=O)OC2C1CCCC1CCCC12</smiles><smiles>C1CCC2(CC1)OCCCO2</smiles><smiles>C=C(C)CCCCCC1CCCC1CCCCCCCC</smiles><smiles>c1ccc(C2CCNCC2)cc1</smiles><smiles>[R]c1cccc(N2CNC(=O)C23CC[NH2+]CC3)c1</smiles><smiles>c1ccc2c(c1)CCC21CCNCC1</smiles><smiles>C1CCC2CNCC2C1</smiles><smiles>[X]C1=C([R])C2CCCC2[X]1</smiles>

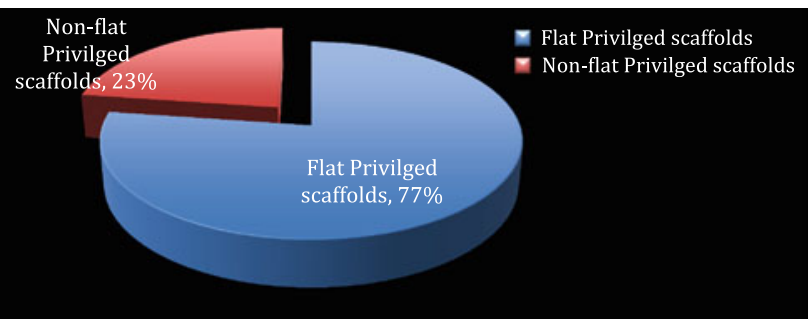

Fig. 5 The distribution of flat and non-flat scaffolds in privileged sub-structure libraries sets were approved drug data set (ADDS; FDA-approved drugs; 1,240 entries), extended drug data set (EDDS composed of FDA-approved drugs and experimental drugs at different phases of clinical trials; 6,932 entries) and screening dataset (SDS; a subset of the "clean-drug-like" molecules in the ZINC database). At the first step, some clean up of the data sets was undertaken to remove small (MW <50 Da) and large (MW >1,000 Da) molecules, duplicated entries, and to eliminate those entries containing elements other than $\mathrm{C}, \mathrm{H}, \mathrm{O}, \mathrm{N}, \mathrm{S}, \mathrm{P}$, and halogens. In the 
Fig. 6 Flatness classification of the RSs in Drug and drug candidates' data sets. The top 50 RSs identified in ADDSs colored black and those RSs in extended drug data set which were absent in the ADDS colored blue
Flat ring systems

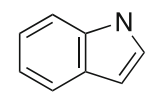<smiles>c1ncc2nc[nH]c2n1</smiles><smiles>c1ncc2[nH]cnc2n1</smiles><smiles>c1ccc2ncccc2c1</smiles><smiles>Clc1cccc(Cl)c1</smiles><smiles>c1ccc2c(c1)Nc1ccccc1S2</smiles><smiles>c1ccc(-c2ccccc2)cc1</smiles><smiles>O=C(CN=Cc1ccccc1)N1C(=O)CN=Cc2ccccc21</smiles><smiles></smiles><smiles>CNc1nc[nH]c(=O)c1N</smiles><smiles>c1ccc(N2Cc3ccccc3N2)cc1</smiles><smiles>O=C1CC(=O)NC(=O)N1</smiles><smiles>O=c1ccoc2ccccc12</smiles><smiles>C1=CC(c2ccccc2)C=CN1</smiles><smiles></smiles><smiles>Clc1ccccc1Cl</smiles><smiles>O=c1cc[nH]c2ccc(F)cc12</smiles><smiles>c1ccc2c(c1)CCCC2</smiles><smiles>c1ccc(N2CCNCC2)cc1</smiles><smiles>c1ccc2c(c1)CCNC2</smiles><smiles></smiles><smiles>c1ncc2ncn(C3CCCO3)c2n1</smiles><smiles>O=C1CN=C(c2ccccc2)c2cc(Cl)ccc2N1</smiles><smiles>O=C1CCNc2ccccc21</smiles><smiles>c1ccc(C2CCCN2)cc1</smiles><smiles>O=c1ncccn1C1CCCO1</smiles><smiles>O=c1cc[nH]c2cc(N3CCNCC3)ccc12</smiles><smiles>c1ccc2c(c1)CCO2</smiles><smiles>Clc1cccc(Cl)c1</smiles><smiles>c1ccc2c(c1)OCCO2</smiles><smiles></smiles><smiles>c1ccc2c(c1)CCCO2</smiles>

Non-flat ring systems<smiles>O=C1CC2SCC=CN12</smiles><smiles>c1ccc(C2CCCC2)cc1</smiles><smiles>C1CCCCC1</smiles><smiles>c1ccc(C2CCNCC2)cc1</smiles><smiles>C1=NCCCC1</smiles><smiles>O=C1C=CC2CCC3C4CCCC4CCC3C2C1</smiles><smiles>O=C1CC2CN1CCS2</smiles>

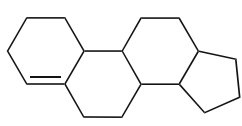<smiles>O=C1C=C2CCC3C4CCCC4CCC3C2CC1</smiles><smiles>C1CC2CCC1C2</smiles>

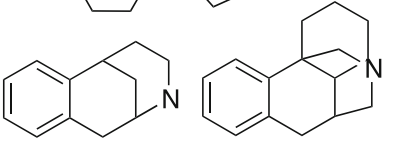<smiles>O=C1C=CC2C(=C1)CCC1C3CCCC3CCC21F</smiles><smiles>c1ccc2c(c1)CCC1C2CCC2CCCC21</smiles><smiles>O=C1C=CC2C(=C1)C(F)CC1C3CCCC3CCC21</smiles><smiles>C1CCC2C(C1)CCC1CCCC12</smiles><smiles>c1cc2c3c(c1)CC1NCCCC31CCC2</smiles><smiles>C1=CC2CCCCC2CC1</smiles><smiles>O=c1ccn(C2CCCO2)c(=O)[nH]1</smiles>

sorted the top 100 DSs identified from FDA-ADDS and EDDS. We used the top 50 RSs obtained from these two drug data sets to investigate how the RSs of drugs are similar to each other in terms of planarity and controlling the geometry of the molecules. We observed that 42 rings systems were common to both data sets. In Fig. 6, we colored the top 50 RSs identified in the ADDS in black and those RSs in the extended drug data set but absent in the first data set (ADDS) in blue. Figure 7 shows the distribution of flat and non-flat scaffolds in the drug data sets. nine heavy atoms". The authors collected and individually 


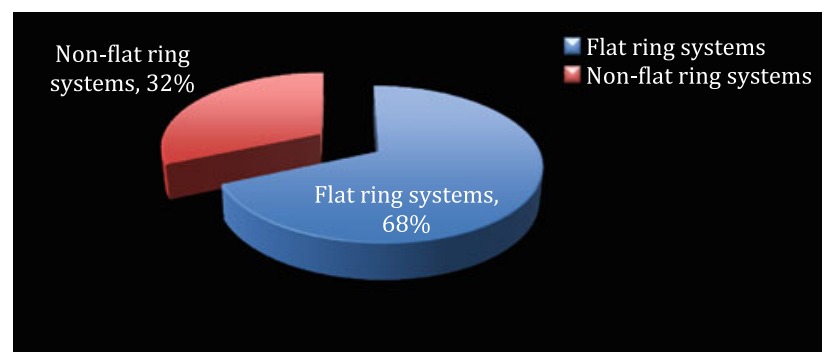

Fig. 7 The distribution of flat and non-flat RSs in drug and drug candidates' data sets

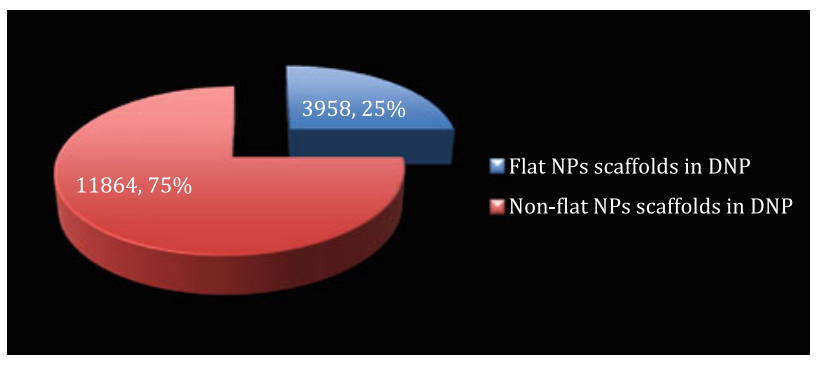

Fig. 9 The distribution of flat and non-flat NP scaffolds extracted from DNP
Fig. 8 Flatness classification of the scaffolds that have been abstracted from DNP

\section{Flat NPs scaffolds in DNP}<smiles></smiles><smiles>c1cc2c3c(ccc-3[nH]1)CS2</smiles><smiles>O=C1CCNc2ccccc21</smiles><smiles></smiles><smiles>c1ccc2nccnc2c1</smiles><smiles>O=C1NCC(=S)N1</smiles><smiles>O=C1CCCOc2ccccc21</smiles><smiles>O=c1ccc2ccccc2o1</smiles><smiles>c1ccc2c(c1)CNC2</smiles><smiles></smiles>

Non-flat NPs scaffolds in DNP<smiles>O=C1CC2CC=CN1C2=O</smiles>

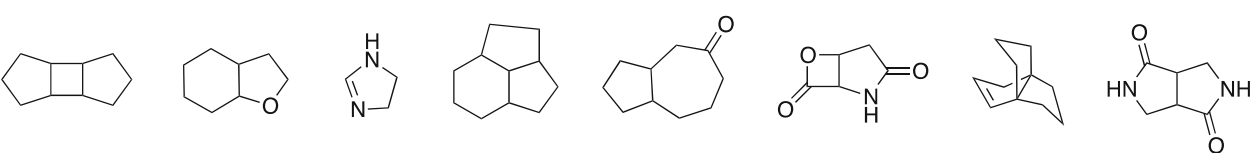<smiles>O=C1CC2CCCC3CCOC(OC3)C2O1</smiles><smiles>C1CN2CCC1C2</smiles><smiles>O=C1C=C2C(C1)CC1CCCC21</smiles><smiles>O=C1CCCCN1C(=O)NCCCO</smiles><smiles>O=C1CC2CCC1C2</smiles><smiles>C1=C2CCC(C1)C2</smiles><smiles>C1=CCC2CCCC2C=C1</smiles><smiles>C1CCC2C(C1)CCC1C2CCC2CC3CCC2C31</smiles><smiles>C1CC2OCCN2C1</smiles><smiles>C1=CC2CCCCC2CC1</smiles><smiles>C1=CC2OC3CCCC2(C1)C3</smiles><smiles>C1CNC2CCCC2C1</smiles><smiles>CC1C2CCCC1C1CCCC21</smiles><smiles>C1NC12COC2</smiles><smiles>NC1CCCC2(CCCCN2)C1</smiles><smiles>C1=CC2OC2C2(C1)CCCCO2</smiles><smiles>O=C1CC2NCCC3CCCC32O1</smiles><smiles>C1CC2OC3CCC4OC4C3N2C1</smiles><smiles>N=C1NC2CCC(N1)OC2</smiles><smiles>C1=CCC23CCOC2OC3C1</smiles><smiles>O=C1OC2C3C=C4CCCN1C4C32</smiles>

The proportion of non-flat RSs compared to planar RSs was 32 versus $68 \%$, respectively.

\section{NP Scaffolds}

Ring scaffolds embedded within all known NPs from The DNPs (sdf version 211.9) were abstracted. All contiguous RSs were extracted with retention of exocyclic double bonds to terminal atoms in order to preserve important chemical functionality. For example, to maintain the carbonyl oxygen present in a lactone or lactam ring.
Metal-containing RSs were excluded from consideration, resulting in the identification of 18,128 RSs. An additional MW filter (MW $<350 \mathrm{Da}$ ) was applied to exclude large, non drug-like RSs (e.g., polycyclic RSs and macrocycles) resulting in 15,822 NP-derived scaffolds.

A number of selected flat and non-flat scaffolds embedded in NPs (abstracted from DNP) are shown in Figs. 8 and 9 and are indicative of the fact that the majority of NP-derived scaffolds are classified as non-flat by considering their corresponding $\mathrm{F}^{3} p^{3}$ values. 


\section{Conclusion}

Examination of $\mathrm{Fsp}^{3}$ values calculated for each scaffold provides further insights into the characteristics that make naturally derived scaffolds appealing when compared to other sources of chemical diversity. Specifically, the predominance of non-flat scaffolds embedded within NPs (i.e., high $\mathrm{Fsp}^{3}$ ) highlights a significant fundamental difference between synthetic and naturally derived compound screening libraries. We propose that the past and continued future success of NPs as a source of therapeutically useful chemical compounds may be attributed to their positioning wholly within regions of BRCS. One characteristic of NPs guiding this complementarity to protein-binding surfaces is the incorporation of non-flat molecular frameworks capable of orienting peripheral functional groups in all three dimensions.

Acknowledgments The research was supported under Australian Research Council Discovery Projects funding scheme (DP130102400).

Open Access This article is distributed under the terms of the Creative Commons Attribution License which permits any use, distribution, and reproduction in any medium, provided the original author(s) and the source are credited.

\section{References}

1. Arya P, Chou DT, Baek MG (2001) Diversity-based organic synthesis in the era of genomics and proteomics. Angew Chem Int Ed Engl 40(2):339-346. doi:10.1002/1521-3773(20010119) 40:2<339:aid-anie339>3.0.co; 2 -j

2. Bahl A, Barton P, Bowers K, Caffrey MV, Denton R, Gilmour P, Hawley S, Linannen T, Luckhurst CA, Mochel T, Perry MW, Riley RJ, Roe E, Springthorpe B, Stein L, Webborn P (2012) Scaffold-hopping with zwitterionic CCR3 antagonists: identification and optimisation of a series with good potency and pharmacokinetics leading to the discovery of AZ12436092. Bioorg Med Chem Lett 22(21):6694-6699. doi:10.1016/j.bmcl.2012.08. 103

3. Beghyn T, Deprez-Poulain R, Willand N, Folleas B, Deprez B (2008) Natural compounds: leads or ideas? Bioinspired molecules for drug discovery. Chem Biol Drug Des 72(1):3-15. doi:10. 1111/j.1747-0285.2008.00673.x

4. Bemis GW, Murcko MA (1996) The properties of known drugs. 1. Molecular frameworks. J Med Chem 39(15):2887-2893. doi:10.1021/jm9602928

5. Bender A, Fergus S, Galloway WR, Glansdorp FG, Marsden DM, Nicholson RL, Spandl RJ, Thomas GL, Wyatt EE, Glen RC, Spring DR (2006) Diversity oriented synthesis: a challenge for synthetic chemists. Ernst Schering Res Found Workshop 58:47-60. doi:10.1007/978-3-540-37635-4_4

6. Bon RS, Waldmann H (2010) Bioactivity-guided navigation of chemical space. Acc Chem Res 43(8):1103-1114. doi:10.1021/ ar100014h

7. Bugni TS, Richards B, Bhoite L, Cimbora D, Harper MK, Ireland CM (2008) Marine natural product libraries for high-throughput screening and rapid drug discovery. J Nat Prod 71(6):1095-1098. doi:10.1021/np800184g

8. Camp D, Davis RA, Campitelli M, Ebdon J, Quinn RJ (2012) Drug-like properties: guiding principles for the design of natural product libraries. J Nat Prod 75(1):72-81. doi:10.1021/ np200687v

9. Camp D, Davis RA, Evans-Illidge EA, Quinn RJ (2012) Guiding principles for natural product drug discovery. Future Med Chem 4(9):1067-1084. doi:10.4155/fmc. 12.55

10. Chen HM, Engkvist O, Blomberg N, Li J (2012) A comparative analysis of the molecular topologies for drugs, clinical candidates, natural products, human metabolites and general bioactive compounds. Med Chem Commun 3(3):312-321. doi:10.1039/ $\mathrm{C} 2 \mathrm{md} 00238 \mathrm{~h}$

11. Consortium IHGS (2004) Finishing the euchromatic sequence of the human genome. Nature 431(7011):931-945. doi:10.1038/ nature 03001

12. Daly JS, Eliopoulos GM, Reiszner E, Moellering RC Jr (1988) Activity and mechanism of action of DuP 105 and DuP 721, new oxazolidinone compounds. J Antimicrob Chemother 21(6):721730. doi: $10.1093 / \mathrm{jac} / 21.6 .721$

13. Dobson CM (2004) Chemical space and biology. Nature 432(7019):824-828. doi:10.1038/nature03192

14. Eustice DC, Feldman PA, Zajac I, Slee AM (1988) Mechanism of action of DuP 721: inhibition of an early event during initiation of protein synthesis. Antimicrob Agents Chemother 32(8):12181222

15. Evans BE, Rittle KE, Bock MG, DiPardo RM, Freidinger RM, Whitter WL, Lundell GF, Veber DF, Anderson PS, Chang RS et al (1988) Methods for drug discovery: development of potent, selective, orally effective cholecystokinin antagonists. J Med Chem 31(12):2235-2246. doi:10.1021/jm00120a002

16. Feher M, Schmidt JM (2003) Property distributions: differences between drugs, natural products, and molecules from combinatorial chemistry. J Chem Inf Comput Sci 43(1):218-227. doi:10. 1021/ci0200467

17. Fink T, Bruggesser H, Reymond J-L (2005) Virtual exploration of the small-molecule chemical universe below 160 Daltons. Angew Chem Int Ed Engl 44(10):1504-1508. doi:10.1002/anie. 200462457

18. Ganesan A (2008) The impact of natural products upon modern drug discovery. Curr Opin Chem Biol 12(3):306-317. doi:10. 1016/j.cbpa.2008.03.016

19. Gembus V, Furman C, Millet R, Mansouri R, Chavatte P, Levacher V, Briere JF (2012) Scaffold hopping strategy toward original pyrazolines as selective CB2 receptor ligands. Eur J Med Chem 58:396-404. doi:10.1016/j.ejmech.2012.10.031

20. Grabowski K, Schneider G (2007) Properties and architecture of drugs and natural products revisited. Curr Chem Biol 1(1):115127. doi: $10.2174 / 187231307779814066$

21. Hann MM, Leach AR, Harper G (2001) Molecular complexity and its impact on the probability of finding leads for drug discovery. J Chem Inf Comput Sci 41(3):856-864. doi:10.1021/ ci000403i

22. Harvey AL (2007) Natural products as a screening resource. Curr Opin Chem Biol 11(5):480-484. doi:10.1016/j.cbpa.2007.08.012

23. Harvey AL (2008) Natural products in drug discovery. Drug Discov Today 13(19-20):894-901. doi:10.1016/j.drudis.2008.07. 004

24. Hert J, Irwin JJ, Laggner C, Keiser MJ, Shoichet BK (2009) Quantifying biogenic bias in screening libraries. Nat Chem Biol 5(7):479-483. doi:10.1038/nchembio. 180

25. Hu Y, Stumpfe D, Bajorath J (2011) Lessons learned from molecular scaffold analysis. J Chem Inf Model 51(8):1742-1753. doi:10.1021/ci200179y 
26. Kellenberger E, Hofmann A, Quinn RJ (2011) Similar interactions of natural products with biosynthetic enzymes and therapeutic targets could explain why nature produces such a large proportion of existing drugs. Nat Prod Rep 28(9):1483-1492. doi:10.1039/c1np00026h

27. Koch MA, Schuffenhauer A, Scheck M, Wetzel S, Casaulta M, Odermatt A, Ertl P, Waldmann H (2005) Charting biologically relevant chemical space: a structural classification of natural products (SCONP). Proc Natl Acad Sci USA 102(48):1727217277. doi:10.1073/pnas.0503647102

28. Koehn FE, Carter GT (2005) The evolving role of natural products in drug discovery. Nat Rev Drug Discov 4(3):206-220. doi: $10.1038 /$ nrd 1657

29. Krier M, Bret G, Rognan D (2006) Assessing the scaffold diversity of screening libraries. J Chem Inf Model 46(2):512-524. doi:10.1021/ci050352v

30. Langdon SR, Brown N, Blagg J (2011) Scaffold diversity of exemplified medicinal chemistry space. J Chem Inf Model 51(9):2174-2185. doi:10.1021/ci2001428

31. Lee M-L, Schneider G (2001) Scaffold architecture and pharmacophoric properties of natural products and trade drugs: application in the design of natural product-based combinatorial libraries. J Comb Chem 3(3):284-289. doi:10.1021/cc0000971

32. Lipinski C, Hopkins A (2004) Navigating chemical space for biology and medicine. Nature 432(7019):855-861. doi:10.1038/ nature 03193

33. Lipinski CA, Lombardo F, Dominy BW, Feeney PJ (2001) Experimental and computational approaches to estimate solubility and permeability in drug discovery and development settings. Adv Drug Deliv Rev 46(1-3):3-26. doi:10.1016/s0169-409x(00) 00129-0

34. Lipkus AH, Yuan Q, Lucas KA, Funk SA, Bartelt WF, Schenck RJ, Trippe AJ (2008) Structural diversity of organic chemistry. A scaffold analysis of the CAS Registry. J Org Chem 73(12):44434451. doi:10.1021/jo8001276

35. Lopez-Vallejo F, Giulianotti MA, Houghten RA, Medina-Franco JL (2012) Expanding the medicinally relevant chemical space with compound libraries. Drug Discov Today 17(13-14):718726. doi:10.1016/j.drudis.2012.04.001

36. Lovering F, Bikker J, Humblet C (2009) Escape from flatland: increasing saturation as an approach to improving clinical success. J Med Chem 52(21):6752-6756. doi:10.1021/ jm901241e

37. Manivannan E, Chaturvedi SC (2012) Analogue-based design, synthesis and docking of non-steroidal anti-inflammatory agents. Part 2: methyl sulfanyl/methyl sulfonyl substituted 2,3-diaryl-2,3dihydro-1H-quinazolin-4-ones. Bioorg Med Chem 20(24):71197127. doi:10.1016/j.bmc.2012.09.069

38. McArdle BM, Campitelli MR, Quinn RJ (2005) A common protein fold topology shared by flavonoid biosynthetic enzymes and therapeutic targets. J Nat Prod 69(1):14-17. doi:10.1021/ np050229y

39. Morton D, Leach S, Cordier C, Warriner S, Nelson A (2009) Synthesis of natural-product-like molecules with over eighty distinct scaffolds. Angew Chem Int Ed Engl 48(1):104-109. doi:10.1002/anie.200804486

40. Newman DJ (2008) Natural products as leads to potential drugs: an old process or the new hope for drug discovery? J Med Chem 51(9):2589-2599. doi:10.1021/jm0704090

41. Newman DJ, Cragg GM (2012) Natural products as sources of new drugs over the 30 years from 1981 to 2010. J Nat Prod 75(3):311-335. doi:10.1021/np200906s

42. Noren-Muller A, Reis-Correa I Jr, Prinz H, Rosenbaum C, Saxena K, Schwalbe HJ, Vestweber D, Cagna G, Schunk S, Schwarz O, Schiewe H, Waldmann H (2006) Discovery of protein phosphatase inhibitor classes by biology-oriented synthesis. Proc Natl
Acad Sci USA 103(28):10606-10611. doi:10.1073/pnas.0601 490103

43. Noren-Muller A, Wilk W, Saxena K, Schwalbe H, Kaiser M, Waldmann H (2008) Discovery of a new class of inhibitors of Mycobacterium tuberculosis protein tyrosine phosphatase B by biology-oriented synthesis. Angew Chem Int Ed Engl 47(32):5973-5977. doi:10.1002/anie.200801566

44. Pelish HE, Westwood NJ, Feng Y, Kirchhausen T, Shair MD (2001) Use of biomimetic diversity-oriented synthesis to discover galanthamine-like molecules with biological properties beyond those of the natural product. J Am Chem Soc 123(27):6740-6741. doi:10.1021/Ja016093h

45. Quinn RJ, Carroll AR, Pham NB, Baron P, Palframan ME, Suraweera L, Pierens GK, Muresan S (2008) Developing a drug-like natural product library. J Nat Prod 71(3):464-468. doi:10.1021/ np070526y

46. Ripka WC, De Lucca GV, Bach AC, Pottorf RS, Blaney JM (1993) Protein $\beta$-turn mimetics I. Design, synthesis, and evaluation in model cyclic peptides. Tetrahedron 49(17):3593-3608. doi:10.1016/s0040-4020(01)90217-0

47. Ritchie TJ, Macdonald SJ (2009) The impact of aromatic ring count on compound developability — are too many aromatic rings a liability in drug design? Drug Discov Today 14(21-22):10111020. doi:10.1016/j.drudis.2009.07.014

48. Rosen J, Gottfries J, Muresan S, Backlund A, Oprea TI (2009) Novel chemical space exploration via natural products. J Med Chem 52(7):1953-1962. doi:10.1021/jm801514w

49. Schreiber SL (2000) Target-oriented and diversity-oriented organic synthesis in drug discovery. Science 287(5460):19641969. doi:10.1126/science.2875460.1964

50. Shelat AA, Guy RK (2007) Scaffold composition and biological relevance of screening libraries. Nat Chem Biol 3(8):442-446. doi:10.1038/nchembio0807-442

51. Singh SB, Barrett JF (2006) Empirical antibacterial drug discovery-foundation in natural products. Biochem Pharmacol 71(7):1006-1015. doi:10.1016/j.bcp.2005.12.016

52. Slee AM, Wuonola MA, McRipley RJ, Zajac I, Zawada MJ, Bartholomew PT, Gregory WA, Forbes M (1987) Oxazolidinones, a new class of synthetic antibacterial agents: in vitro and in vivo activities of DuP 105 and DuP 721. Antimicrob Agents Chemother 31(11):1791-1797. doi:10.1128/aac.31.11.1791

53. Spandl RJ, Diaz-Gavilan M, O'Connell KM, Thomas GL, Spring DR (2008) Diversity-oriented synthesis. Chem Rec 8(3):129-142. doi:10.1002/tcr.20144

54. Sun H, Tawa G, Wallqvist A (2012) Classification of scaffoldhopping approaches. Drug Discov Today 17(7-8):310-324. doi:10.1016/j.drudis.2011.10.024

55. Wang J, Hou T (2010) Drug and drug candidate building block analysis. J Chem Inf Model 50(1):55-67. doi:10.1021/ci900398f

56. Welsch ME, Snyder SA, Stockwell BR (2010) Privileged scaffolds for library design and drug discovery. Curr Opin Chem Biol 14(3):347-361. doi:10.1016/j.cbpa.2010.02.018

57. Weskamp N, Hullermeier E, Klebe G (2009) Merging chemical and biological space: structural mapping of enzyme binding pocket space. Proteins 76(2):317-330. doi:10.1002/prot.22345

58. Wess G, Urmann M, Sickenberger B (2001) Medicinal chemistry: challenges and opportunities. Angew Chem Int Ed Engl 40(18):3341-3350. doi:10.1002/1521-3773(20010917)40:18< 3341:aid-anie3341>3.0.co;2-d

59. Wester MJ, Pollock SN, Coutsias EA, Allu TK, Muresan S, Oprea TI (2008) Scaffold topologies. 2. Analysis of chemical databases. J Chem Inf Model 48(7):1311-1324. doi:10.1021/ ci700342h

60. Wetzel S, Bon RS, Kumar K, Waldmann H (2011) Biologyoriented synthesis. Angew Chem Int Ed Engl 50(46):10800 10826. doi:10.1002/anie.201007004 
61. Wong JC, Tang G, Wu X, Liang C, Zhang Z, Guo L, Peng Z, Zhang W, Lin X, Wang Z, Mei J, Chen J, Pan S, Zhang N, Liu Y, Zhou M, Feng L, Zhao W, Li S, Zhang C, Zhang M, Rong Y, Jin TG, Zhang X, Ren S, Ji Y, Zhao R, She J, Ren Y, Xu C, Chen D, Cai J, Shan S, Pan D, Ning Z, Lu X, Chen T, He Y, Chen L (2012) Pharmacokinetic optimization of class-selective histone deacetylase inhibitors and identification of associated candidate predictive biomarkers of hepatocellular carcinoma tumor response. J Med Chem 55(20):8903-8925. doi:10.1021/jm3011838

62. Wu S, Yang L, Gao Y, Liu X, Liu F (2008) Multi-channel counter-current chromatography for high-throughput fractionation of natural products for drug discovery. J Chromatogr A 1180(1-2):99-107. doi:10.1016/j.chroma.2007.12.024

63. Xu Z, Yan G, Wang G, Li B, Zhu J, Sun P, Zhang X, Luo C, Wang H, Zhu W (2012) Combining pharmacophore, docking and substructure search approaches to identify and optimize novel B-RafV600E inhibitors. Bioorg Med Chem Lett 22(17):5428-5437. doi:10.1016/j.bmcl.2012.07.039

64. Ye D, Shin WJ, Li N, Tang W, Feng E, Li J, He PL, Zuo JP, Kim H, Nam KY, Zhu W, Seong BL, No KT, Jiang H, Liu H (2012) Synthesis of C-4-modified zanamivir analogs as neuraminidase inhibitors and their anti-AIV activities. Eur J Med Chem 54:764-770. doi:10.1016/j.ejmech.2012.06.033

65. Yu J, Liu H, Xia G, Liu L, Xu Z, Chen Q, Ma C, Sun X, Xu J, Li H, Li P, Shi Y, Xiong B, Liu X, Shen J (2012) Discovery of 2-alkyl-1-arylsulfonylprolinamides as $11 \beta$-hydroxysteroid dehydrogenase type 1 inhibitors. ACS Med Chem Lett 3(10):793-798. doi: $10.1021 / \mathrm{ml} 300144 \mathrm{n}$ 